In cooperation with the Texas Commission on Environmental Quality

\title{
Summary of Annual Mean and Annual Harmonic Mean Statistics of Daily Mean Streamflow for 620 U.S. Geological Survey Streamflow-Gaging Stations in Texas Through Water Year 2007
}

Data Series 372 
Cover: Photograph of unnamed personnel verifying water level (stage) using a graduated staff gage and sitting on intake for stilling well at U.S. Geological Survey streamflow-gaging station 08118500 Bull Creek near Ira, Tex. in Fall 1947 (see fig. 388). 